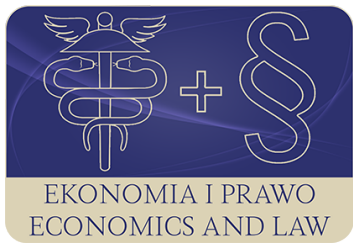

EKONOMIA I PRAWO
ECONOMICS AND LAW
EKONOMIA I PRAWO. ECONOMICS AND LAW Volume 17, Issue 3, September 2018 p-ISSN 1898-2255, e-ISSN 2392-1625 www.economicsandlaw.pl

ORIGINAL ARTICLE received 02.01.2018; revised 09.05.2018; accepted 30.09.2018

Citation: Tendera-Właszczuk, H. (2018). Study on the Brexit's background and causes. Ekonomia i Prawo. Ecomomics and Law, 17(3): 307-317. doi:10.12775/EiP.2018.022.

\title{
Study on the Brexit's background and causes
}

\section{HELENA TENDERA-WEASZCZUK}

Cracow University of Economics, Faculty of Economics and International Relations, Department of European Economic Integration, ul. Rakowicka 27, 31-510 Kraków, Poland

$\square$ tendera@uek.krakow.pl

\begin{abstract}
Motivation: The results of the in-out referendum on the United Kingdom's membership in the European Union has shown that the European project, understood as a process of political integration within the EU is not stable. The economic crisis as well as the migration crisis has started new discussion on the European project and its weaknesses. The British decision to leave the European Union significantly influences the conditions of the EU functioning and future. There is no doubt that the present situation is the most serious crisis in the history of the European integration.

Aim: The aim of the paper is to analyze the hybrid model of integration and its influence on the United Kingdom's decision to exit from the European Union and to broaden our understanding of the factors influencing that decision. The specific position of the United Kingdom in the EU will be analyzed. The history of the UK membership in the EU and the fundamental tension in the Member States' debates concerning the model of integration will be discussed. The current situation represents a trade-off between two rival, federal and confederal, models of integration. The weaknesses of the present model of integration and its influence on the current state of the EU will be discussed.

Results: From the very beginning the UK membership in the EU has been marked by many tensions. One of the most important problem was the discussion on the future model of the integration. The paper demonstrates that the present European integration hybrid model is the main reason for the EU crisis and the United Kingdom's decision to leave the European Union.
\end{abstract}

Keywords: European Union; Brexit; European integration model; European integration crisis JEL: F02; F50; O52 


\section{Introduction}

The outcome of the referendum regarding Great Britain's future membership in the European Union, which took place on the 23rd June 2016, shook public opinion in all the Member States. The 65-year long European integration process, initially only covering Western European countries and after the fall of communism also Central and Eastern European countries, is the most important political project after the Second World War. It has ensured peaceful coexistence and the overcoming of animosity between the aggressors and victims of the two world wars. The project was regarded as a success not only politically, but also economically, as a region of peace, security, prosperity, justice and respect for human rights. The progressive process of deepening integration as well as membership expansion and its associated increase in mutually exclusive interests of Member States has caused tension within the group and discussions regarding the model of integration.

In 2000, the European Union entered a period of debate over its future shape and the possible further scenarios for the integration process. The debate began with the drafting of the Treaty establishing a Constitution for Europe, intended to introduce significant changes to the European Union and its Member States and to base the functioning of the union to a greater extent on federal principles. The failure to ratify the treaty, its rejection, the subsequent drafting of the Lisbon Treaty, and the latter's entry into force coincided with the global economic crisis, whose repercussions significantly impacted the economic and social conditions within the union. At the same time, the crisis has laid bare a clear deficit of political leadership in the European project, and exposed the difficulties in establishing a political vision for the future character of the European Union and its role an position in the world.

The ongoing process of the federalisation of the European Union has been causing discontent or even resistance from Member States, which was reflected in the result of the British referendum, where the majority voted to leave the community. This article attempts to prove a hypothesis that the causes of the exit vote were a lack of acceptance of the current integration model and a lack of a common concept among Member States regarding the further development of the integration process. Brexit not only significantly damages the image of the European Union on the international stage, but it is a present threat to the cohesion of the European project and to its future. Brexit is not a zero-sum game. There are no losers and winners. Both sides, that is the European Union as well as Great Britain are losers. Brexit does not lie in the interest of either the European Union or Great Britain.

\section{Literature review}

There is an extensive literature on Brexit. The reasons as well as consequences are frequently examined. We will concentrate on Brexit's causes according 
to the thesis of this article. The decision of Tony Blair government from 2003 to permit full freedom of movement to the citizens of ten new Member States is at the root of the future decision of Britons to vote to leave the EU. A very high inflow of workers into the UK and its significant impact on employee's pay level was an important issue (Somai \& Biedermann, 2016, pp. 137-156). The Merkel's decision from 2015 to open borders for 1 million of immigrants from Africa and the Middle East countries was important for the results of the referendum (Hunt \& Wheeler, 2016). Growing euroscepticism in the UK and the British sovereignty are mentioned by Gifford (2016). The negative image of Brussels bureaucrats as well as the role of eurosceptic media during campaign before referendum are mentioned by Craig (2016, pp. 447-486).

\section{Methods}

Desk research containing the economic and political studies using combined methods of comparative analysis and theoretical synthesis of federal and confederal models of integration will be the research method. Author use historical as well as contemporary theoretical studies and personal reflection based on ongoing research. Descriptive and comparative analysis are the research tools used in the article. The fundamental tension in the Member States' debates concerning the model of integration will be discussed. The current situation represents a trade-off between two rival, federal and confederal, models of integration. An incoherent, hybrid model has evolved and largely contributed to the current crisis of the European Union, which is the central argument of this article.

\section{Results}

\subsection{Great Britain's position towards the integration processes in Western Europe until the 1960s}

During the post-war period Great Britain actively partnered with West European countries. In Zurich in 1946 Winston Churchill proposed the idea of forming the 'United States of Europe'. Britain was actively involved in the rebuilding of European economies after their destruction during the war. Great Britain was one of the founders of the Organisation for European Economic Co-operation (OEEC) and the main beneficiary of the Marshall Plan. However, in the 1950s, Great Britain showed a sceptical attitude towards the integration processes in Europe because of a federal integration model promoted by France.

Additional British doubts were raised by the idea of creating a customs union and the introduction of a common customs tariff for goods from outside the community because of Britain's strong economic links with other Commonwealth countries. It was especially true for trade. Nearly $75 \%$ of British trade was conducted within the Commonwealth (Childs, 2001, p. 42). Britain 
also worked closely with the United States. Also, the British people maintained a strong feeling of superiority over other countries, as rulers of the Empire where the sun never sets, encompassing a quarter of the world's population (Greenleaf, 1983, pp. 357-358).

Another argument against GB membership of any of the European Communities was its reluctance towards political engagement, in particular the concept of forming a European Defence Community and a European Political Community.

In 1960, Great Britain together with Austria, Denmark, Sweden, Switzerland, Portugal and Norway formed the European Free Trade Association. In the 1960s these countries recorded lower economic growth (2.0\%) compared with the Member States of the EEC (6.5\%). The British empire was also gradually falling apart (Kitzinger, 1973, p. 85). Due to these reasons, on the 22 July 1961, Prime Minister Harold Macmillan applied for Britain to join the European Communities. However, in July 1963 Charles de Gaulle, the president of France, vetoed the motion which prevented GB from joining.

Britain expressed its will to join the European Communities for a second time on the 2 May 1967. The application was filed by Harold Wilson who was Prime Minister at the time. Again France's veto blocked the process. It was only the subsequent president of France, Georges Pompidou, who supported Britain's membership efforts (Bartlett, 1977, pp. 38-50). The accession negotiations started in June 1970 and the accession treaty was signed on the 22 January 1972.

\subsection{Great Britain's 'difficult' membership in the European Communities/Union}

Great Britain joined the European Communities on the 1st January 1973. From the very beginning of membership, she was a difficult partner and a rebel. 1974 saw the first negotiations of Britain's conditions of membership in the EEC. Among the demands regarding issues such as the financing of the Communities or additional support for British farming, there were clear calls directly challenging the accepted integration model and the excessive interference of European institutions in the economies of the Member States. These attitudes were made evident by Britain's lack of agreement regarding the harmonisation of VAT and insisting that economic policy should be implemented at the national level. In a referendum on the 5th June 1975, British voters cast their ballots on whether to continue their membership in the EEC. As many as $67 \%$ were in favour of remaining in the Communities (Butler \& Kitzinger, 1976, p. 30).

Another example of the lack of acceptance of the deepening integration was Britain's refusal to join the European Monetary System in 1979.

The clearly negative attitude towards Union policies was expressed by the Prime Minister at the time, Margaret Thatcher, who in her speech in Bruges in 1988 said that, "the EEC is a super-state exercising a new dominance from 
Brussels'. She also accused EU politicians of over-protectionism and negotiated a rebate for Britain. Similar views were expressed by Prime Minister Tony Blair in 2001. He emphasised that the foundation of Europe should be made of strong, sovereign countries. He demanded changes be made to the spending of the Union budget through the reduction of spending on a common agricultural policy and an increase in spending on research, new technologies and the creation of new jobs.

\subsection{The hybrid model of integration as a source of conflict within the union: the position of Great Britain}

Since the 1950s, there has been an ongoing debate about the model of European integration (Godino \& Verder, 2014; Hallstein, 1962; Streeten, 1964, pp. 1-176; 2001). Various visions have competed, with two basic conceptions, the confederal and the federal model, at the forefront. The moot point in the debate concerns the function of the nation state in the integration process and, in particular, the restriction of its legislative autonomy for the sake of supranational institutions. Another basic issue regards the scope of competence of EU institutions and their influence on legislation in view of the fact that each represents a different interest group (Wessels, 2014). The idea of a Europe of Nations, championed by Charles de Gaulle, assumed that Member States would have the final say in decision-making, with only very limited prerogatives delegated to the supranational level. The proposed visions of the federal model, on the other hand, were very different: Spinelli called for the creation of a European federal state, Monnet, on the other hand, proposed a gradual advance toward a federation through forging real bonds between countries based on their shared interests (Dąbrowski, 2016; Tendera-Właszczuk, 2016, p. 1014).

The founding treaties establishing the European Coal and Steel Community, the European Economic Community, and the European Atomic Energy Community, never adopted a common vision of the European integration model. However, the confederal model first took precedence. Only very limited powers were granted to the Parliament (earlier: The Parliamentary Assembly). Deputies represented the national parliaments of Member States and the institution did not have any direct influence on the decision-making process. Procedures did not allow it to introduce amendments to the drafts of secondary law acts, and the Council could, by unanimous vote, force through its position even against the will of the Parliament. Accordingly, it was the Council of Ministers, which represented the interests of individual Member States, that held the greatest sway over decision-making.

The Merger Treaty, which entered into force in 1967, incorporated certain elements of the federal model by introducing the common Commission of the European Communities which represented the interests of the community as a whole. 
The Single European Act further deepened the process of European federalization by introducing the principle of qualified majority voting in the Council and granting greater prerogatives to the Parliament. Other federal innovations included the adoption of a single internal market, the implementation of a number of new policies at the community level, and a number of changes to budget principles (fund-raising, introduction of multi-year financial frameworks).

The Maastricht Treaty constituted a turning point in the advance towards the federal model, by introducing the 2nd and 3rd pillar of the European Union: the Common Foreign and Security Policy, and Justice and Home Affairs. The move did not involve a new division of powers between Members States and the supranational institutions, since the cooperation on matters within the 2nd and 3rd pillar was based on the principle of intergovernmental cooperation.

The adoption of the co-decision procedure further reinforced the role of the Parliament in the legislative process. Other important decisions that clearly indicated the growth in strength of the federal vision include the name, European Union, the common citizenship, and the decision to introduce an economic and monetary union, adopt a common currency, and establish the European Central Bank. Countries that adopted a common currency lost their sovereignty in terms of shaping financial and monetary policy.

The Amsterdam Treaty, on the other hand, introduced a new post, that of a representative of the union for foreign affairs and security policy.

Based on the Lisbon Treaty, the European Union acquired legal subjectivity and became an international organization. The treaty invested the European Council with institutional status and defined its prerogatives, establishing the post of the President of the European Council. In addition, it strengthened the role of the European Parliament and created the High Representative of the Union for Foreign Affairs and Security Policy, who heads the Council for Foreign Affairs and acts as the deputy president of the European Commission.

The Lisbon Treaty introduced, effective as of 1 November 2014, a new voting mechanism in the Council of the European Union that replaced the principle of triple majority with the principle of double majority. The principle of double majority in qualified majority voting means that a decision must be approved by at least $55 \%$ of members, each of which enjoys one vote, representing countries with the combined population of no less than $65 \%$ of the total population of the European Union. The system strengthens the position of the original Member States, the EU-15, in the legislative process, allowing them to take decisions without the participation of new members, which was impossible under the Nice system. The power of the new countries has now diminished also because they can no longer block decisions (as they do not meet the population requirement). They could still do so under the Nice system (Tendera-Właszczuk, 2016, pp. 1014-1017).

The analysis clearly indicates the prevalence of federal over confederal elements. The system at hand thus represents a trade-off between two competing 
visions; it can be referred to as a hybrid integration model and combines federal and confederal features.

Confederal elements include:

- respect for diversity and national identity;

- support for cultural and linguistic diversity;

- the principle of subsidiarity;

- elements of decision-making based on the principle of unanimity;

- institutions that represent the national interests of member states, such as the Council of the European Union and the European Council;

- the decisive role of the Council of the European Union (equal to that of the European Parliament) in the decision-making process and secondary legislation;

- the role of national parliaments in secondary legislation (the yellow and orange card procedure).

Federal elements include:

- the status of the European Union as an international organization;

- legal subjectivity;

- supranational institutions such as the European Commission, the European Central Bank, the European Parliament, the Court of Justice of the European Union, the European Court of Auditors

- the Committee of Regions and the European Economic and Social Committee, based on the principle of social participation;;

- the post of the President of the European Council with wide-ranging powers, colloquially referred to as the president of the European Union

- the post of the High Representative of the Union for Foreign Affairs and Security Policy;

- the post of the European Ombudsman;

- the diminished role of unanimity in the decision-making process and an increase in importance of qualified majority voting;

- the move away from the principle of triple majority towards the principle of double majority in qualified majority voting;

- the strong role of the European Parliament in secondary legislative process;

- the implementation of common policies and the reinforcement of the principle of the exclusive competences of the union;;

- the adoption of the principle of the primacy of community legislation and the direct effect of the norms of European law

- the introduction of the common budget and multi-year financial frameworks;

- the strengthening of the role of the European Commission in terms of controlling the budget policy of Member States;

- the principle of granting common citizenship, an EU citizenship, to all EU residents;

- the implementation of an economic union and the introduction of a common currency; 
- common symbols that were not laid down in the Lisbon Treaty: the EU flag, the EU anthem, the Europe Day.

As shown above, subsequent revisions of EU treaties have not finally settled the issue of the integration model. The hybrid model makes it impossible to achieve consensus on many essential issues that act as a source of conflict within the union. These issues include, to name but a few (Tendera-Właszczuk, 2016, p. 1019):

- the conflict between the net payers and net beneficiaries of the EU budget;

- the inability to implement certain elements of the single internal market;

- the lack of participation of some countries in the Schengen zone;

- the monetary union does not include all member states (the opt-out clause, derogations);

- no common position on the fiscal compact;

- no common position on the fiscal and banking union;

- no common energy policy;

- widening disproportions in the development of regions and countries: inability to meet the goal of economic, social, and territorial cohesion;

- no common position on the further expansion of the European Union (e.g. the accession of Turkey);

- no common position on the distribution of immigrants and the functioning of the Schengen zone.

Great Britain frequently opposed the further process of integration undertaken by the other member states. As a result, it achieved special conditions for its membership in the European Union, namely, it remained outside the Schengen and euro zones (Gifford, 2016, pp. 779-794). Regarding the Charter of Fundamental Rights, it negotiated separate terms in the form of the British Protocol with an opt-out option. It also did not formalize the Treaty on Stability, Coordination and Governance in the Economic and Monetary Union of 2011, which entered into force on the 2 March 2012. Thus it remains outside of the Fiscal Compact. Britain frequently stated that it found itself isolated because it was not able to attend the euro group summits (led by the duo of France and Germany) and had no say in determining the direction of Union policy.

\subsection{Euroscepticism as a reason for Brexit}

Euroscepticism is growing within the EU. In 2016 only 33\% of Europeans trusted the EU, with 27\% negatively inclined towards it. By comparison, in $2006,50 \%$ of Europeans had a positive attitude towards it and $15 \%$ were negative. Over the same period trust towards the EU in Britain dropped from 36\% to $20 \%$ (VoxEurop, 2017).

The reasons for such a state of affairs can be ascribed to, firstly, the lack of stability within the EU as reflected in the economic crisis (2008+), the democratic crisis, the crisis within the EU institutions and the migrant crisis. Secondly, Euroscepticism is the result of the crisis regarding the concept of the European 
project with member states campaigning for changes to the current integration model (Craig, 2014; Habermas, 2012).

The proof in support of these theses is the speech made by David Cameron in London on the 23rd January 2013 in which he severely criticized the condition of the EU, pointing to the institutional and functional crisis of the European Union which evidenced itself in the crisis of the democratic legitimacy of Union institutions, the Eurozone crisis, a drop in the competitiveness of the European economy and a lack of an appropriate EU response to its internal problems (Euronews, 2015). Additionally, he stated that the Union lacks an appropriate response to the changes occurring on the international arena, which weakens its position in the world. As a result, he pointed to the necessity of increasing the EU's competitiveness, improving the flexibility of its actions and creating a network of economic links. He also demanded the increase in sovereignty of Member States through the strengthening of the role of national parliaments and the repatriation of certain competencies from EU to national level. Additionally, he appealed for a just and equal treatment of Member States and for an end to the discrimination against countries outside the Eurozone. Finally, he announced that a referendum would be held in Britain regarding its continuation within the EU (Emerson, 2013, pp. 1-6).

On the 18th and 19th February 2016 Great Britain renegotiated its EU membership conditions. The main points concerned:

- increased sovereignty for Great Britain;

- increased emphasis on the principle of subsidiarity;

- the exclusion of Britain from the principle of 'an ever closer union';

- the strengthening of the role of national parliaments which are entitled to block Union laws.

The referendum was carried out on the 23rd June 2016. The turnout was very high at $72.2 \%$ of those entitled to vote. The majority of Britons, that is $51.9 \%$ chose to leave the EU while 48.1\% wanted to remain (Craig, 2016, pp. 447-486; Hunt \& Wheeler, 2016; Somai \& Biedermann, 2016, pp. 137-156). Most Europeans were surprised by the outcome of the referendum, expecting the result to be a warning to the Union elites that will cause changes in the principles of the European project and trigger solutions that will overcome the Union's institutional and functional crises (Davies, 2016; Wintour, 2016).

\section{Conclusion}

Brexit lead to the conclusion that the European project is far from stable. The exit of Britain from the EU will upset a certain long-standing balance, which despite the often-opposing interests of the Member States allowed for the integrity of the community to be preserved. In the author's opinion, the main reason for Brexit stems in large measure from the failure of the Member States to agree on and adopt common premises and priorities regarding the integration 
model. This applies both to the political doctrine and the model of economic integration.

Subsequent revisions of EU treaties have not finally settled the issue of the integration model. The hybrid model makes it impossible to achieve consensus on many essential issues that act as a source of conflict within the union. Multi-speed Europe has now become a fact and the segmentation of the European Union is permanent.

The hybrid model of integration that has evolved since the 1950s out of the federal and confederal models shows that the growing crisis within the EU cannot be overcome; it is a permanent process and any possible solutions will merely constitute stopgap measures addressing current problems caused by external or internal factors. The European project, however, is and has always been a political construct. For this reason, as long as there is enough support for the project and political will, the process of European integration will continue.

\section{References}

Bartlett, C.J. (1977). A history of postwar Britain. London: Longman.

Butler, D., \& Kitzinger, U. (1976). The 1975 referendum. Basinstoke: Macmillan. Childs, D. (2001). Britain since 1945. London-New York: Routledge.

Craig, P. (2014). The United Kingdom, the European Union, and Sovereignty. In R. Rawlings, P. Leyland, \& A. Young (Eds.), Sovereignty and the law: domestic, European and international perspectives. Oxford: Oxford Scholarship Online. doi:10.1093/acprof:oso/9780199684069.003.0010.

Craig, P. (2016). Brexit: a drama in six acts. European Law Review, 41(4).

Dąbrowski, M. (2016). The future of the European Union: towards a functional federalism. Acta Oeconomica, 66(1). doi:10.1556/032.2016.66.S1.2.

Davis, J. (2016). Brexit: what now for the United Kingdom and Europe? EuroChoices, 15(3). doi:10.1111/1746-692X.12136.

Emerson, M. (2013). Cameron's big speech on Europe - No, Prime Minister! CEPS Essay, 3.

Euronews. (2015). Explained Cameron and the EU: what does a Brexit mean? Retrieved 03.05.2017 from http://www.euronews.com.

Gifford, C. (2016). The United Kingdom's eurosceptic political economy. The British Journal of Politics and International Relations, 18(4). doi:10.1177/1369148116652776.

Godino, R., \& Verder, F. (2014). Heading towards a European federation: Europe's last chance. Notre Europe Policy Paper, 105.

Greenleaf, W.H. (1983). The British political tradition. London: Routledge.

Habermas, J. (2012). The crisis of the European Union: a response. Malden: Polity Press.

Hallstein, W. (1962). United Europe: challenge and opportunity. Cambridge: Harvard University Press. 
Hunt, A., \& Wheeler, B. (2016). The UK's EU referendum: all you need to know. Retrieved 20.02.2017 from http://www.bbc.com.

Kitzinger, U. (1973). Diplomacy and persuasion: how Britain joined the common market. London: Thames and Hudson.

Somai, M., \& Biedermann, Z. (2016). Brexit: reasons and challenges. Acta Oeconomica, 66(1). doi:10.1556/032.2016.66.S1.8.

Streeten, P. (1964). Economic integration: aspects and problems. Leyden: Styhoff.

Streeten, P. (2001). Integration, interdependence and globalization. Finance and Development. A Quarterly Magazine of the IMF, 38(2).

Tendera-Właszczuk, H. (2016). Analysis of the sources of the European Union crisis. Ostrava: Technical University of Ostrava.

VoxEurop. (2017). Retrieved 20.02.2017 from http://www.voxeurop.eu.

Wessels, W. (2014). The political implication of European economic integration. Paper presented at the Jean Monnet Conference on Political Implications of European Economic Integration, Brussels.

Wintour, P., \& Syal, R. (2016). Brexit would damage EU and UK' 'politically and economically'. Retrieved 20.02.2017 from http://www.theguardian.com.

\section{Acknowledgements}

Author contributions: author has given an approval to the final version of the article.

Funding: this research was financed from the funds allocated to the University of Economics in Krakow to maintain the research potential of the European Economic Integration Chair.

Note: the results of this study were presented at 9th International Conference on Applied Economics Contemporary Issues in Economy (June 22-23, Toruń, Poland). 
